\title{
Front Matter: Volume 11379
}

, "Front Matter: Volume 11379," Proc. SPIE 11379, Sensors and Smart Structures Technologies for Civil, Mechanical, and Aerospace Systems 2020, 1137901 (26 May 2020); doi: 10.1117/12.2572576 


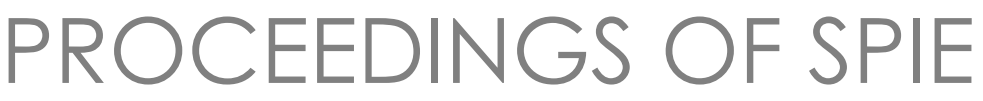

\title{
Sensors and Smart Structures Technologies for Civil, Mechanical, and Aerospace Systems 2020
}

\author{
Haiying Huang \\ Hoon Sohn \\ Daniele Zonta \\ Editors
}

27 April-8 May 2020

Online Only, United States

Sponsored by

SPIE

Cooperating Organizations

Jet Propulsion Laboratory (United States)

Published by

SPIE 
The papers in this volume were part of the technical conference cited on the cover and title page. Papers were selected and subject to review by the editors and conference program committee. Some conference presentations may not be available for publication. Additional papers and presentation recordings may be available online in the SPIE Digital Library at SPIEDigitalLibrary.org.

The papers reflect the work and thoughts of the authors and are published herein as submitted. The publisher is not responsible for the validity of the information or for any outcomes resulting from reliance thereon.

Please use the following format to cite material from these proceedings:

Author(s), "Title of Paper," in Sensors and Smart Structures Technologies for Civil, Mechanical, and Aerospace Systems 2020, edited by Haiying Huang, Hoon Sohn, Daniele Zonta, Proceedings of SPIE Vol. 11379 (SPIE, Bellingham, WA, 2020) Seven-digit Article CID Number.

ISSN: 0277-786X

ISSN: 1996-756X (electronic)

ISBN: 9781510635357

ISBN: 9781510635364 (electronic)

Published by

SPIE

P.O. Box 10, Bellingham, Washington 98227-0010 USA

Telephone +1 3606763290 (Pacific Time) · Fax +1 3606471445

SPIE.org

Copyright (c) 2020, Society of Photo-Optical Instrumentation Engineers.

Copying of material in this book for internal or personal use, or for the internal or personal use of specific clients, beyond the fair use provisions granted by the U.S. Copyright Law is authorized by SPIE subject to payment of copying fees. The Transactional Reporting Service base fee for this volume is $\$ 21.00$ per article (or portion thereof), which should be paid directly to the Copyright Clearance Center (CCC), 222 Rosewood Drive, Danvers, MA 01923. Payment may also be made electronically through CCC Online at copyright.com. Other copying for republication, resale, advertising or promotion, or any form of systematic or multiple reproduction of any material in this book is prohibited except with permission in writing from the publisher. The CCC fee code is $0277-$ $786 \mathrm{X} / 20 / \$ 21.00$.

Printed in the United States of America by Curran Associates, Inc., under license from SPIE.

Publication of record for individual papers is online in the SPIE Digital Library.

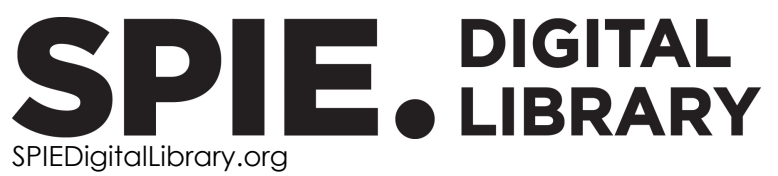

Paper Numbering: Proceedings of SPIE follow an e-First publication model. A unique citation identifier (CID) number is assigned to each article at the time of publication. Utilization of CIDs allows articles to be fully citable as soon as they are published online, and connects the same identifier to all online and print versions of the publication. SPIE uses a seven-digit CID article numbering system structured as follows:

- The first five digits correspond to the SPIE volume number.

- The last two digits indicate publication order within the volume using a Base 36 numbering system employing both numerals and letters. These two-number sets start with $00,01,02,03,04$, 05, 06, 07, 08, 09, OA, OB ... 0Z, followed by 10-1Z, 20-2Z, etc. The CID Number appears on each page of the manuscript. 


\section{Contents}

\section{KEYNOTE SESSION}

1137903 Machine learning for structural health monitoring: challenges and opportunities (Keynote Paper) [11379-2]

NOVEL SENSOR AND SENSING TECHNOLOGIES I

1137904 Wireless crack detection of a concrete building using low-cost RFID tags [11379-3]

1137905 Dynamic validation of a strain-based 3D shape sensing system [1 1379-4]

MACHINE LEARNING FOR SMART STRUCTURES

1137908 Online input, state, and response estimation for building structures under earthquakes using limited acceleration measurements [11379-8]

1137909 A Bayesian network-based decision framework for managing bridge scour risk [11379-9]

$11379 \mathrm{OB} \quad$ Damage sizing in self-sensing materials using a genetic algorithm-supplemented electrical impedance tomography formulation [11379-11]

11379 OC Artificial intelligence-based smart engineering education [11379-12]

11379 OD Automatic segmentation of ultrasonic TFM phased array images: the use of neural networks for defect recognition [11379-13]

ELECTROMECHANICAL IMPEDANCE (EMI)-BASED SHM

11379 Ol Resonances of surface-bonded piezoelectric wafer active transducers and their effects on the SO pitch-catch signal [11379-18]

NOVEL SENSORS AND SENSING TECHNOLOGIES II

11379 OK Moving sensors in structural dynamics [11379-21]

$11379 \mathrm{OL} \quad$ Evaluating the ride quality of unpaved roads using smartphones [11379-22] 
11379 OM Pressure distribution of a deformable composite flapping wing [11379-23]

\section{ENERGY HARVESTING TECHNIQUES}

11379 ON Seismic energy dissipation of periodic assembly tensegrity system [1 1379-24]

$1137900 \quad$ Magnetostrictive vibration power generator from vehicle-induced highway vibrations for battery free LPWA module with titanium wire sensor [11379-25]

11379 OR Micro magnetostrictive vibrational power generator for battery-free wireless sensor in machine tool [1 1379-28]

11379 OT Extra-large magnetostrictive vibrational power generator for bridge health monitoring [1 1379-30]

11379 OU A low-noise three-axis piezoelectric MEMS accelerometer for condition monitoring [11379-31]

NOVEL PIEZOELECTRIC TRANSDUCERS

$113790 Z \quad$ Auxetic MEMS sensor [11379-36]

1137912 Strain sensing using flexible surface acoustic wave sensor [11379-39]

IMAGING-BASED SHM

$1137914 \quad$ Nondestructive debonding detection of fiber reinforced plastics strengthened structure based on infrared thermal imaging with laser thermal excitation [11379-41]

$1137916 \quad$ Flexible planar solar phase array antenna analysis for low Earth orbit space-based sensors [1 1379-43]

1137918 Algorithm assessment for layup defect segmentation from laser line scan sensor based image data [1 1379-45]

$1137919 \quad$ High-speed motion blur compensation system in infrared region using galvanometer mirror and thermography camera [11379-46]

\section{OPTICAL FIBER SENSORS}

11379 1C Imaging 3T3 cells in photonic crystal fibers [11379-49]

iv 
11379 1D Modeling of ultrasound generation by a polymer composite based fiber-optic photoacoustic transducer [11379-50]

11379 IE Optimization of sensor placement for guided waves based SHM using fiber Bragg grating sensors [11379-51]

$11379 \mathrm{IF} \quad$ Self-referencing ultrasound detection of fiber Bragg grating sensor remotely bonded at two locations [11379-52]

\section{PASSIVE ULTRASOUND INSPECTION TECHNIQUES}

11379 1G Defect detection performance of a high-speed rail inspection system from passive acoustic identification [11379-54]

$1137911 \quad$ Automatic boiler tube leak detection with deep bidirectional LSTM neural networks of acoustic emission signals [11379-56]

\section{ACTUATOR TECHNOLOGIES FOR SMART STRUCTURES}

11379 1K Brake-by-wire actuator featuring magnetorheological fluid clutch [1 1379-58]

$113791 \mathrm{~L} \quad$ Experimental investigation of an active mass damper with acceleration feedback sliding mode control [11379-59]

11379 IN Parametric optimization of continuum mechanisms incorporating active material actuation [11379-62]

\section{NANO-COMPOSITE AND FLEXIBLE SENSORS}

1137910 The effect of extrusion temperature and cycles on electrical resistivity in carbon nanofibermodified PLA filament for multi-functional additive manufacturing [1 1379-65]

11379 IP Additive manufacturing of magnetostrictive thin film sensors [11379-67]

$113791 Q \quad$ Large-area electronic skins in space: vision and preflight characterization for first aerospace piezoelectric e-textile [1 1379-68]

\section{POSTER SESSION}

11379 1R Sensing of dispersion and adhesion by 2D Electrical Resistance (ER) mapping of MWCNT in polyurethane nanocomposites for aircraft topcoat [11379-66]

11379 is Optimization of magnetorheological brake and its ABS bench test [11379-70] 
$113791 \mathrm{~N} \quad$ Nondestructive evaluation of the effect of electrochemical corrosion on anodized aluminum specimens under mechanical cyclic loading [1 1379-75]

$1137919 \quad$ Numerical simulation and evaluation of aerodynamic configuration of the fairing for the national measurement standard of air flow velocity [11379-76]

1137912 Compensation method for torsional stiffness of flexible wing [11379-77]

$1137921 \quad$ Application of wavelet denoising and a masking signal for flutter boundary prediction [11379-79]

1137922 Design and analysis of flexible skin for variable camber wing [1 1379-80]

$1137923 \quad$ Flutter boundary prediction under continuous variable speed based on time series models [11379-81]

$1137924 \quad$ Noncontact inspection of the curing process of cementitious materials by laser Doppler vibrometry [11379-82]

1137926 Research on the Buck-Boost converter based on the Smart Lm5116 [11379-85]

$1137927 \quad$ Kinematics analysis and simulation of a smart eight-joint tandem robot [11379-86]

$1137928 \quad$ Estimation of tire stiffness variation based on adaptive extended Kalman filter of suspension systems and its application to indirect tire pressure monitoring system [1 1379-87]

1137929 A method to overcome wireless communication limits in decentralized active control applications [1 1379-88]

11379 2A Application of a virtual inerter in active vibration control using inertial actuators [1 1379-89]

$113792 \mathrm{E} \quad$ Static structural health monitoring and automated data analysis procedures applied to the diagnosis of a complex medieval masonry monastery [11379-94]

$113792 \mathrm{~J} \quad$ Numerical and experimental investigations of pure $M X e n e\left(\mathrm{Ti}_{3} \mathrm{C}_{2} \mathrm{TX}\right)$ film and $M X$ Xene nanocomposites for structural health monitoring [1 1379-99] 